\title{
Corporate Social Responsibility: Issues Challenges and Strategies for Indian Firms
}

\author{
*Yasmin Begum R. Nadaf **Shamshuddin M. Nadaf \\ ${ }^{I}$ Asst. Professor, Dept of Commerce, Rani Chennamma University, Belgaum. Karnataka India \\ Email: yasminmehak@gmail.com. \\ ${ }^{2}$ Asst. Professor, Government First Grade College, Dharwad, Karnataka India \\ Email:Shamshuddin71@gmail.com
}

\begin{abstract}
Today Businesses are an integral part of the society. Michael Sabia, President and Chief Executive Officer of BCE Inc., has said, "Corporations are also social institutions. The role of business, according to this model, is to create value for its shareholders and also creates value for society, manifesting itself as a win-win proposition. Corporate success during these days is highly based on continued good relations with a wide range of individuals, groups and institutions. Corporate Social Responsibility plays vital role in winning the customer's confidence that will help growing the business. Many organizations actively conduct campaigns to create awareness among corporate, civic bodies, and government bodies about the importance of corporate social responsibility.

The term corporate responsibility has been captioned under many names including corporate citizenship, social responsibility. CSR as described by Lord Holme and Richard Watts in 'Making Good Business Sense'. Society began to expect business to voluntarily participate in solving societal problems whether they had caused those problems or not. Report on Business Magazine recently noted that "many business leaders now believe that doing good for others means doing good for shareholders as well."

Corporate social responsibility is a process in which all companies come together as one and take part in the welfare of the society. It is often referred to as business responsibility and an organization's action on environmental, ethical, social and economic issues. New legal mandates were imposed to ensure equal employment opportunities, product safety, worker safety, and environmental protection. Companies with high CSR standards are able to demonstrate their responsibilities to the stock holders, employees, customers, and the general public.

As per United Nations and the European Commission, Corporate Social Responsibility (CSR) leads to triple bottom-line: profits, protection of environment and fight for social justice. Economist and philosopher Adam Smith suggested that the needs and desires of society could best be met by the free interaction of individuals and organizations in the marketplace. However, it is still in nascent stage in India. A recent survey reveals that 79 percent of Americans prefer to buy products of companies that actively engage in corporate social responsibility events.
\end{abstract}

In this connection Indian business world should go beyond their economic and legal obligations to establish mutual trust and accept responsibilities related to the betterment of society.

The papers discuss the role of corporate social responsibility. Paper also underlines the major issues/challenges faced by Indian firms, and suggests remedial measures for effective implementation of CSR initiatives.

Important terms: Corporate social responsibility, issues, challenges, remedial measures

\section{Introduction:}

'........ Our social responsibility is reflected by the variety of the actions we take and by our projects to support safety, education, diversity and the environment.

-Carlos Ghosn, Chairman and CEO of Renault

Today Businesses are an integral part of the communities. It is evident that business build civilizations. Corporate Sectors have a key role in the socio-economic development of any country. There are many instances where corporate have played a dominant role in addressing issues of education, health, environment and livelihoods through their corporate social responsibility interventions across the globe. It is important for the corporate sector to identify, promote and implement successful policies and practices. As per United Nations and the European Commission, Corporate Social Responsibility (CSR) leads to triple bottom-line: profits, protection of environment and fight for social justice.

According to the Indian Corporate, "Sustainable development implies optimizing financial position while not depleting social and environmental aspects and CSR implies supporting issues related to children, women and environment". It has become progressively projected in the Indian corporate setting because 
organizations have recognized that besides growing their businesses, it is also important to shape responsible and supportable relationships with the community at large.

\section{Theoretical Background:}

Corporate Social Responsibility (CSR) evolved from its early beginnings in the 1950's. CSR as a concept found its feet more in Europe than in the US. United Nations played a significant role in universal acceptance of the idea of CSR.

The topic of corporate responsibility has been captioned under many names, including strategic philanthropy, corporate conscience, corporate citizenship, social performance, sustainable responsible business. According to Dr Ratnam the concept of CSR had different meanings depending on the stakeholder and that depending on the specific situation. Forms of CSR differ according to the country or region.

The term "corporate social responsibility" came into common use in the late 1960s and early 1970s as a result of an influential book by R. Edward Freeman, Strategic management: a stakeholder approach in 1984.

Corporate social responsibility is the procedure of assessing an organization's impact on society and evaluating their responsibilities. Corporate social responsibility is a form of corporate self regulation integrated into a business modal.

Corporate social responsibility is sustainable - involving activities that an organization can uphold without negatively affecting the business goals. Corporate social responsibility begins with an assessment of the following aspects of each business;

- Customers

- Suppliers

- Environment

- Communities

- Employees

The expectations of the public have grown enormously with demands focusing and forcing companies to take affirmative action. Over time of the cultural norms of corporations' engagement changed In India whereas In Europe notions of CSR probably developed out of the Church and a sense of ethics. In the late '90s, when consumers first started to become aware of workers' rights violations in factories around the world, apparel and footwear brands became the target.

Today, after years of intense focus on the apparel and footwear industries, people are beginning to realize that urgent action is needed in other sectors, too.

\section{Why Corporate Social Responsibility?}

Corporate Social Responsibility main aim is to embrace responsibility for the company's actions and encourage a positive impact through its activities on the environment, consumers, employees, communities, stakeholders and all other members of the public spare. There are many numbers of business models developed in order to achieve CSR objectives. Being a good corporate citizen the companies have to be internally well governed and externally responsible. In other words, CSR and corporate governance are two sides of the same coin.

The following are some of the drivers pushing business towards Corporate Social Responsibility.

1 The Shrinking Role of Government: Shrinking government resources, coupled with a distrust of regulations, has led to the exploration of voluntary and non-regulatory initiatives instead.

2 Demands for Greater Disclosure including customers, suppliers, employees, communities, investors, and activist organizations.

3 Increased Customer Interest: In a recent survey by Environics International, more than one in five consumers reported having either rewarded or punished companies based on their perceived social performance.

4 Growing Investor Pressure: The Social Investment Forum reports that in the US in 1999, there was more than $\$ 2$ trillion worth of assets invested in portfolios that used screens linked to the environment and social responsibility. A separate survey by Environics International revealed that more than a quarter of share-owning Americans took into account ethical considerations when buying and selling stocks.

5 Competitive Labour Markets: Employees are increasingly looking beyond paychecks and benefits, and seeking out employers whose philosophies and operating practices match their own principles. In order to hire and retain skilled employees, companies are being forced to improve working conditions.

6 Supplier Relations: As stakeholders are becoming increasingly interested in business affairs, many companies are taking steps to ensure that their partners conduct themselves in a socially responsible 
manner are introducing codes of conduct for their suppliers, to ensure that other companies' policies or practices do not tarnish their reputation.

\section{Phases Of Corporate Social Responsibility:}

Among other countries India has one of the richest traditions of CSR. CSR has gone through many phases in India.

The history of CSR in India has its four phases which run parallel to India's historical development and has resulted in different approaches. However the phases are not static and the features of each phase may overlap other phases.

In the first phase charity and philanthropy were the main drivers of CSR. In the second phase, during the independence movement, there was increased stress on Indian Industrialists to demonstrate their dedication towards the progress of the society. The third phase of CSR (1960-80) had its relation to the element of "mixed economy" led to enactment of legislation regarding corporate governance, labour and environmental issues. In the fourth phase (1980 until the present) Indian companies started abandoning their traditional engagement with CSR and integrated it into a sustainable business strategy.

In 1990s the first initiation towards globalisation and economic liberalisation were undertaken. A concern for social and environmental development should be made a part of every corporate entity through its inclusion in the annual agenda backed by strong and genuine programs on/for status of employees, mobility of staff, work hours, social relations, health and safety, training, health policy, profits distribution, Outsourcing etc., Increased growth momentum of the economy helped Indian companies grow rapidly and this made them more willing and able to contribute towards social cause.

In a survey, All 82 participating organizations were asked to rate the companies with CSR initiatives and indicate their preference for best three companies. TATA Group (67 per cent) emerges as the front runner distantly followed by Infosys (13 per cent), ITC (12 per cent), NTPC (11 per cent) and ADA-Reliance (10 per cent).

In spite of having such good glorious examples; In India CSR is in a very much budding stage. A lack of understanding, inadequately trained personnel, coverage, policy etc. further adds to the reach and effectiveness of CSR programs.

\section{Opportunities For Stakeholders:}

Corporate social responsibility (CSR) is an important function to accelerate the process of overall development and nation-building. India, the second most populous country in the world and home to the largest number of people in need of basic amenities, needs more intensive efforts as part of CSR covering the length and breadth of the country.

Because of the growing size and power of multinational corporate houses, bond rating agencies and investment funds are exerting increasing influence. Some of the positive outcomes that can arise when businesses adopt a policy of social responsibility include:

\section{Benefits for Corporate:}

- Improved financial performance;

- Lower operating costs;

- Enhanced brand image and reputation;

- Increased sales and customer loyalty;

- Greater productivity and quality;

- More ability to attract and retain employees;

- Reduced regulatory oversight;

- Access to capital;

- Workforce diversity;

- $\quad$ Product safety and decreased liability

Benefits to the Community and the General Public:

- Charitable contributions

- Employee volunteer programs

- Corporate involvement in community education, employment and homelessness programs

- $\quad$ Product safety and quality

\section{Environmental Benefits:}


- Greater material recyclability;

- Better product durability and functionality;

- Greater use of renewable resources;

- Integration of environmental management tools into business plans, including life-cycle assessment and costing, environmental management standards, and eco-labeling.

A growing trend in large multinational corporations is the establishment of special committees within the board of directors to oversee CSR and sustainable business practices. There are many positive aspect of how companies have managed their CSR strategies well and are reaping the benefits.

\section{Challenges For Indian Corporate:}

The concept of corporate social responsibility is now firmly rooted on the global business agenda. But in order to move from theory to concrete action, many obstacles need to be overcome. A key challenge facing business is the need for more reliable indicators of progress in the field of CSR, along with the dissemination of CSR strategies. Transparency and dialogue can help to make a business appear more trustworthy, and push up the standards of other organizations at the same time.

A lack of understanding, inadequately trained personnel, non availability of authentic data and specific information on the kinds of CSR activities, coverage, policy etc. further adds to the reach and effectiveness of CSR programmes. But the situation is changing.

In his widely-cited book entitled Misguided Virtue: False Notions of Corporate Social Responsibility (2001) David Henderson argued forcefully against the way in which CSR broke from traditional corporate value-setting. He questioned the "lofty" and sometimes "unrealistic expectations" in CSR. Some argue that CSR is merely window-dressing, or an attempt to pre-empt the role of governments as a watchdog over powerful multinational corporations.

The Times survey pointed few of the following challenges/responses from participating organisations.

- Lack of community participation in CSR activities

- Need to build local capacities:

- Issues of transparency:

- Non-availability of well organised non-governmental organisations:

- Visibility factor:

- Narrow perception towards CSR initiatives:

- Non-availability of clear CSR guidelines:

- Lack of consensus on implementing CSR issues:

India's tryst with destiny heralded more than 60 years ago, is yet to be fulfilled. For all the progress that has undeniably been made, it is as if time has stood still in India's villages. The corporate India based in and around cities has been flourishing and marching ahead whereas rural India still remains desperately poor. In this connection the corporate India can play a key role in bridging the gap of urban and rural India.

The success of CSR lies in practicing it as a core part of a company's development strategy. It is important for the corporate sector to identify, promote and implement successful policies and practices that achieve triple bottom line results. It is a joint and shared responsibility of civil society, activist groups, Government and corporate sector to create appropriate means and avenues for the marginalized and bring them to the mainstream.

The CSR survey revealed, not surprisingly, those organisations targeted most of their activities close to home - providing services for people who live in villages, towns, and districts near where the organisation operates. Education, health, and the environment are the top priorities. More than likely, these priorities will continue.

To create a win-win situation, it is essential for all of us to work together to alleviate abject poverty and improve miserable living conditions that exist in rural India.

\section{Suggestions:}

In order to meet the expectations of all our stakeholders, we must surround ourselves with all components of business and society. Corporate competitiveness is partly based on ability to adapt products, services and management to the challenges of constantly changing societies. To do this, we need to identify, support and develop the best CSR initiatives

In order to crystal gaze the future of CSR in India and take time bound steps to mainstream it, few recommendations are suggested.

1. To create awareness about CSR amongst the general public to make CSR initiatives more effective. 
2. CSR as a subject or discipline should be made compulsory at B-schools, in colleges and universities to sensitise students about social and development issues

3. To develop partnerships between all stakeholders including the private sector, employees, local communities, the Government and society.

4. Extend CSR initiatives/activities to small, medium and large corporate houses.

5. CSR initiatives and programmes are taken up in urban areas and localities.

6. Corporate houses and NGOs should actively involved in pooling their resources and building synergies to implement best CSR practices to scale up projects and innovate new ones to reach out to more beneficiaries.

7. Government should recognizing and reward corporate houses/NGOs and their partners' in effective implementing projects for the poor and the underprivileged.

8. Partnerships between the Government and other interest groups have been well defined in policy documents at all levels and to develop common strategies to translate policy pronouncements into demonstrable action agendas

9. Lay more focus on education, health, environment protection, livelihood, women empowerment, disaster management, green marketing, ethical practices, etc., and other social and community relevance issues

10. To underline the Government's policy documents to ensure 'public co-operation' in planning process of CSR initiatives

11. Innovative models are to be popularize among corporate in these areas

12. In order to push the development agenda in a mission mode, it is recommended that realistic and operational models are jointly explored and addressed

13. A growing number of corporate feel that CSR is not just another form of indirect expense but is important for protecting the goodwill and reputation, defending attacks and increasing business competitiveness.

14. Research by global organizations pointed out that business leaders must be the most credible, most ethical, least corrupt and most value-driven in the world. Regardless of the label, the dominant paradigm underlying corporate social responsibility is centered on the idea of creating "shared value."

15. Partnerships between companies, NGOs and the government should be facilitated so that a combination of their skills such as expertise, strategic thinking, manpower and money to initiate extensive social change will put the socio-economic development of India on a fast track.

In this context, Indu Jain, Chairperson, The Times of India Group New Delhi rightly opined "Corporate Social Responsibility Practices in India sets a realistic agenda of grassroots development through alliances and partnerships with sustainable development approaches. At the heart of solution lies intrinsic coming together of all stakeholders in shaping up a distinct route for an equitable and just social order..." which eventually paves way for harmonious convergence of innovative ideas with appropriate execution methodology.

\section{Corporate Social Responsibility: A Road Ahead...}

Corporate Social Responsibility is gaining position and corporate houses are realising that 'what is good for workers - their community, health, and environment is also good for the business'. Corporate Social Responsibility is not new to Indian corporate like the Tata Group, the Aditya Birla Group, Infosys and Indian Oil Corporations, etc., a few have been involved in serving the community for social good in their operations for decades long before CSR become a popular cause.

In spite of having such life size successful examples, CSR in India is in a very nascent stage. There is much to learn about building world-class CSR programmes in the Indian context. According to Carlos Ghosn, Chairman and CEO of Renault, It is our responsibility, and it is in our own interest, to become involved in the social and societal lives of the countries where we do business.'

It is pointed that the continuing commitment by business to behave ethically and contribute to economic development while improving the quality of life of the workforce and their families as well as of the local community and society at large"

\section{Conclusion:}

There is evidence that the ethical conduct of companies exerts a growing influence on the stakeholder's decisions. Simply launching charitable trusts and foundations when the workplace environment is vitiated does not serve the company's purpose. Presently in India, it is hard for one sole entity to bring about change, as the gauge is vast. Large enterprises can no longer continue to focus only on economic performance, without paying attention to what is happening around them. Hence, the overriding conclusion is that companies need to be mature and realize that they must practice socially conscious policies. 
To conclude CSR as a business imperative must not be accepted grudgingly or half heartedly. Instead, it must be practiced with full vigor and straight from the heart passion and this certainly helps the companies' in the long run meaningful impact on society and its future is bright in coming years. After all, business is by the people, for the people and of the people.

\section{References:}

[1]. Chahoud, Dr. Tatjana; Johannes Emmerling, Dorothea Kolb, Iris Kubina, Gordon Repinski, Catarina Schläger (2007). Corporate Social and Environmental Responsibility in India - Assessing the UN Global Compact's Role.

[2]. "Desirable Corporate Governance: A Code", established in April 1998.

[3]. CSR in India: Some Theory and Practice in Wall Street Journal dated Thursday, April 23, 2009.

[4]. Khanna, Parul; Gitika Gupta, Status of Corporate Social Responsibility: In Indian Context,January 2011

[5]. Sathish, Ramya. "Corporate Social Responsibility in India - Putting Social-Economic Development on a Fast Track"

[6]. P. Cappelli, H. Singh, J. Singh, \& M. Useem, The India Way, Academy of Management Perspectives, 24, 2, May 2010, page 6-24.

[7]. Trust and Corporate Social responsibility: Lessons from India by Ashwani Singla, Chief Executive Officer, \& Prema Sagar, Founder \& Principal, Genesis Public Relations Pvt. Ltd.

[8]. Business Line, Business Daily from THE HINDU group of publications, Wednesday, Jun 23, 2010.

[9]. http://www.chillibreeze.com/articles_various/CSR-in-India.asp.

[10]. http://www.iisd.org/business/issues.

[11]. www.k4d.org/Health/sustainable-development-challenges-and-csr-activities-in-india. 